\title{
Validation of isoniazid for therapeutic drug monitoring in human plasma by high- performance liquid chromatography
}

By Dyah Aryani Perwitasari 


\section{AIP $\mid$ Conferenne Proceedings}

1

Validation of isoniazid for therapeutic drug monitoring in human plasma by highperformance liquid chromatography

S. P. V. D. Jaikishin, D. A. Perwitasari, E. Darmawan, U. A. Mulyani, and J. Atthobari

Citation: AIP Conference Proceedings 1746, 020030 (2016); doi: 10.1063/1.4953955

View online: http://dx.doi.org/10.1063/1.4953955

View Table of Contents: http://scitation.aip.org/content/aip/proceeding/aipcp/1746?ver=pdfcov

Published by the AIP Publishing

Articles you may be interested in

Validation of pyrazinamide in human plasma using Hplc-Uv for therapeutic drug monitoring

AlP Conf. Proc. 1746, 020031 (2016); 10.1063/1.4953956

5

Accurate measurement of dopant concentration in organic light-emitting diodes by combining high-performance liquid chromatography and TOF-SIMS

J Vac. Sci. Technol. B 32, 030604 (2014); 10.1116/1.4871756

14

Carbon Nanotube Stationary Phase in a Microfabricated Column for High-Performance Gas Chromatography

AlP Conf. Proc. 1137, 249 (2009); 10.1063/1.3156518

18

Baseline Noise in High-Performance Liquid Chromatography with Electrochemical Detection

AIP Conf. Proc. 780, 643 (2005); 10.1063/1.2036834

High-performance liquid chromatography fraction marker-timer controller

Rev. Sci. Instrum. 62, 3102 (1991); 10.1063/1.1142162 


\title{
Validation of Isoniazid for Therapeutic Drug Monitoring in Human Plasma by High-Performance Liquid Chromatography
}

\author{
S.P.V.D. Jaikishin ${ }^{1, a)}$, D.A. Perwitasari ${ }^{1, b)}$, E. Darmawan ${ }^{1, c)}$, U.A. Mulyani ${ }^{2, d)}$, J. \\ Atthobari, ${ }^{3, e}$ \\ ${ }^{I}$ Faculty of Pharmacy, Universitas Ahmad Dahlan, Yogyakarta \\ ${ }^{2}$ Basic Technology Center for Biomedical and Health Research and Development Board of Health,Jakarta \\ ${ }^{3}$ Faculty of Medicine, Universitas Gadjah Mada, Yogyakarta \\ b) Corresponding author: diahperwitasari2003@yahoo.com \\ s) sheila.pvdj@yahoo.com \\ c) enddarmawan@googlemail.com \\ d) ullyadhie@gmail.com \\ e) j.atthobari@gmail.com
}

\begin{abstract}
Isoniazid is one of anti-tuberculosis agentwhich can cause hepatotoxicity. However, not all of the TB patients and health providers can recognize early sympton 6 of antituberculosis-induced hepatotoxicity. Thus, the Therapeutic Drug Monitoring needs to be performed to monitor the hepatotoxicity symptoms. The aim of this study is to establish the validity of the Isoniazid assay method using High-Performance Liquid Chromatography from human ${ }^{\text {plasma. We }}$ recruited 6 healthy subjects for this validation study. The validation was performed using Shimadzu HPL 21 stem with a model AT LC20 LC 10AT pump, detector SPD 20A and LC solution software. We used C18 column shim- pack VPODS $(250 \mathrm{~mm} \times 4.6 \mathrm{~mm}$, id $-5 . \mathrm{m})$ as well as other tools such as centrifuges, vortex, appliance glass (Pyrex IWAKI) and other supporting tools. Che 4 als and solvents was used from Merck Germany. Isoniazid standard compounds were obtained from SIGMA. Our study has been approved by National Ethics Committee of Health Research Pur study shows that the method applied in HPLC has the good linearity $(\mathrm{r}=0.998)$ with coefficient of variande $1 \mathrm{CV}$ ) of system appropriateness test is $0.61 \%$ and the equation of linearity was $y=8756.87 x+27724.82$. The value of Limit of Detection (LoD) and Limit of Quantification (LOQ) were $1.517 \mu \mathrm{g} / \mathrm{ml}$ and $4.597 \mu \mathrm{g} / \mathrm{ml}$, respectively. The precision on the concentration of $0,5,5.0,15.0 \mathrm{ug} / \mathrm{ml}$ are $5.24 \%, 0.79 \%, 2.83 \%$, respectively for intraday precision and $4.86 \%, 2.18 \%$; $2.01 \%$, respectively for interday precision. The recoveries on the particular concentrations are $100.79 \% ; 108.91 \%$; $92.19 \%$, respectively for intraday recovery and $101.73 \% ; 99.63 \% ; 82.75 \%$, respectively for interday recovery. This validation method is a good alternative for the application of TDM in monitoring the treatment of TB patients' clinical practice
\end{abstract}

Keywords: Validation, isoniazid, therapeutic, monitoring

\section{BACKGROUND}

Currently, Indonesia is in the $5^{\text {th }}$ rank of the highest tuberculosis prevalence over the world [1]. Since 1995, WHO introduced the Directly Observed Treatment Shortcourse (DOTS) program, and this program has been proven as effective in controlling the tuberculosis disease. The mortality rate decrease about $45 \%$ and the tuberculosis prevalence decrease about $42 \%$. However, the incidence of tuberculosis is still high [1,2]

Anti-tuberculosis agents which used in the treatment of tuberculosis are isoniazide, rifampicin, ethambutol and pyrazinamide. One of the most popular side effect due to the use of the medications are hepatotoxicity $[3,4]$. Isoniazid is the most possible drug caused hepatotoxicity due to its toxic metabolite [5].

The incidence of hepatotoxicity due to the use of antituberculosis was $20 \%$ [6]. Due to the long duration of treatment of tuberculosis, we need to do the monitoring of hepatotoxicity symptomps and provide the appropriate treatment [7]. One of the method to do the monitoring is Therapeutic Drug Monitoring (TDM) which is one part of

19

The 2016 Conference on Fundamental and Applied Science for Advanced Technology (ConFAST 2016)

AIP Conf. Proc. 1746, 020030-1-020030-5; doi: 10.1063/1.4953955

Published by AIP Publishing. 978-0-7354-1403-7/\$30.00

020030-1 
the pharmaceutival care services [8]. TDM may help the physician to understand about the complexity treatment of tuberculosis and also help the physician to decide about the dose or treatment recommended after having the results of TDM [9]

Isoniazid or Isonicotinic acid Hidrazide (INH) is a whit 2 colorless crystals or white crystalline powder and odorless. It is slowly affected by air and light and is easily soluble in water, sligh 25 oluble in ethanol, sparingly soluble in chloroform and in ether. INH is well absorbed in the gastrointestinal after oral administration and is distributed throughout the body. Its peak concentration in serum is depend on the dose administered. The peak serum levels achieved within 1-3 hours after oral administration and the effective concentration was found 24 hours after the drug is swallowed. The average half-life in fast acetylators reaches nearly 80 minutes, while the value of hours is typical for slow acetylator [10].

This study objective is to to establish the validity of the Isoniazid assay method using High-Performance Liquid Chromatography from human plasma

\section{METHODS}

\section{Subjects}

We recruited 6 healthy subjects as volunteer of blood plasma sample. The blood was taken 2 hour after the antituberculosis agents were taken by the patients. We gave the infor $4 \mathrm{~d}$ consent to the subject and asked them to signature the informed consent form as the agreement for participation in this study. Our study has been approved by the National Ethic Committee of Health Research.

\section{Reference Compound and Reagents}

Chemicals and solvents used from Merck Germany, among others: methanol pro analysis (pa) (3906609839), Diethyl ether pa, Trichlor solution of acetic acid (TCA) 10\% pa (3639707643), pa Acetonitrile (1632730213) and aquabidest. The isoniazid as standard compounds was obtained from SIGMA.

\section{Chromatographic Conditions}

This study used a Shimadzu HPLC system with a model of AT LC20 LC 10AT 4 mp, detector SPD 20A and LC solution software. The column used was a C18 column shim- pack VP-ODS ( $250 \mathrm{~mm} \times 4.6 \mathrm{~mm}$, id $5 \mu \mathrm{m})$. Mobile phase consisted of Aquabidest : Acetonitrile (97:3)\% with flow rate $1 \mathrm{~mL} /$ minute, UV detection at a wavelength of $262 \mathrm{~nm}$, retention time 15 minute and inject volume $20 \mu \mathrm{L}$.

\section{Preparation of plasma standards and samples}

The standard samples were prepared from $450 \mu \mathrm{l}$ of plasma, then added by $50 \mu \mathrm{l}$ validation solution to make $5.00 ; 50.00$ and $150.00 \mu \mathrm{g} / \mathrm{mL}$. The solution concentrations for linearity were $0.5 ; 1.00 ; 3.00 ; 5.00$ and $15.00 \mu \mathrm{g} / \mathrm{mL}$. The solution concentrations for accuracy, intraday and interday recision were $0.5 ; 5.0 ; 15.00 \mu \mathrm{g} / \mathrm{mL}$

The $1000 \mathrm{~mL}$ of $10 \%$ TCA was added onto each the concentration solutions then follow these procedures such as; 20 seconds of vortex for with a maximum speed and 10 minutes of centrifuged at a speed of $13000 \mathrm{rpm}$, temperature of $4^{\circ} \mathrm{C}$. The supernatant was poured into the tube and added by $3 \mathrm{~mL}$ of ether. The extraction was performed using these procedures; 20 seconds of vortex and 10 minutes of centrifuged at $4000 \mathrm{rpm}$. Finally, the 20 $\mathrm{mL}$ water phase was injected into the HPLC $[11,12]$

\section{Validation Method}

The validation method of INH using HPLC was modified from the previous studies [11,12]. We used HPLC due to this instrument has high selectivity and sensitivity and it also can perform the analysis with small cancentration of sample using UV adsorben detector [13]

\section{System Suitability}

The system suitability was examined from the one point of $20 \mu \mathrm{L}$ solution from standard curve which was injected into HPLC. We replicated this method for six times. From the chromathoghraph we defined the coefficient of variance $(\mathrm{CV})$ of retention time and wide of area ratio $[14,15]$

\section{Linearity}

The equation of linier regression: $y=b x+a$ described the association between INH concentration and area wide ratio of chromatoghraph or the high of chromatoghraph peak. The calibration curve was used to defined the sample concentration. $[14,15]$. 


\section{$L o D$ and $L o Q$}

The value of LoD and LoQ were defined from the equation and standar of deviation (SD). LoD was defines as signal and noise ratio $(\mathrm{S} / \mathrm{N})$ with the 3:1 comparation. The LoQ was defined using 10:1 comparation of S/N. $[14,15]$

\section{Accuracy}

The recovery describes the value of accuracy. The Area Under the Curve (AUC) of isoniazid was processed by linear regression equation to get the actual levels. The value of recovery can be seen from the average $\%$ of recovery or actual levels divided theoretical level and multiplied by $100 \%$. The value of good recovery was $80-120 \%$. $[14,15]$

\section{Intra-day and Inter-day precision}

Intra-day precision values can be seen from the \% of coefisien of variance (CV) of each replication. The method met the requirements of precision if the value of the average $\%$ CV was $<15 \%$. $[14,15]$

\section{RESULTS}

The results of this study are listed in Table 1 . The suitability system shows the $\mathrm{CV} \mathrm{T}_{\mathrm{R}}$ and $\mathrm{CV}$ peak area are $0,26 \%$ and $0,61 \%$ respectively. The equation for regression linier of $0.5 ; 1 ; 3 ; 5 ; 10$; dan $15 \mu \mathrm{g} / \mathrm{mL}$ concentration is $y=8756.873 x+27724.816$, with $r=0,998$. The regression linier can be seen in Graph 1 . The LoD and LoQ met the criteria of FDA and ICH $[14,15]$ which are $1.571 \mu \mathrm{g} / \mathrm{mL}$ and $4.597 \mu \mathrm{g} / \mathrm{mL}$, respectively.

TABLE 1. Results of validation measurement for INH using HPLC

\begin{tabular}{ccc}
\hline Parameter & Required Criteria ${ }^{*}$ & Results \\
\hline System suitability & $\mathrm{CV} \leq 2 \%$ & $\mathrm{CV} \mathrm{T}_{\mathrm{R}}=0,26 \%$ \\
& & $\mathrm{CV}$ peak area $=0,61 \%$ \\
inearity & $\mathrm{r} \geq 0,99$ & $\mathrm{r}=0,998$ \\
LOD & $\mathrm{S} / \mathrm{N} \approx 3: 1$ & $\mathrm{y}=8756.873 \mathrm{x}+27724.816$ \\
LOQ & $\mathrm{S} / \mathrm{N} \approx 10: 1$ & $1,517 \mu \mathrm{g} / \mathrm{mL}$ \\
\hline
\end{tabular}

$\mathrm{CV}=$ coefisien of variance $; \mathrm{T}_{\mathrm{R}}=$ Retention Time; $\mathrm{r}=$ Coefficient of correlation; $\mathrm{LOD}=$ Limit of Detection; $\mathrm{LOQ}$

$=$ Limit of Quantification. *Adopted from [14]; [15]

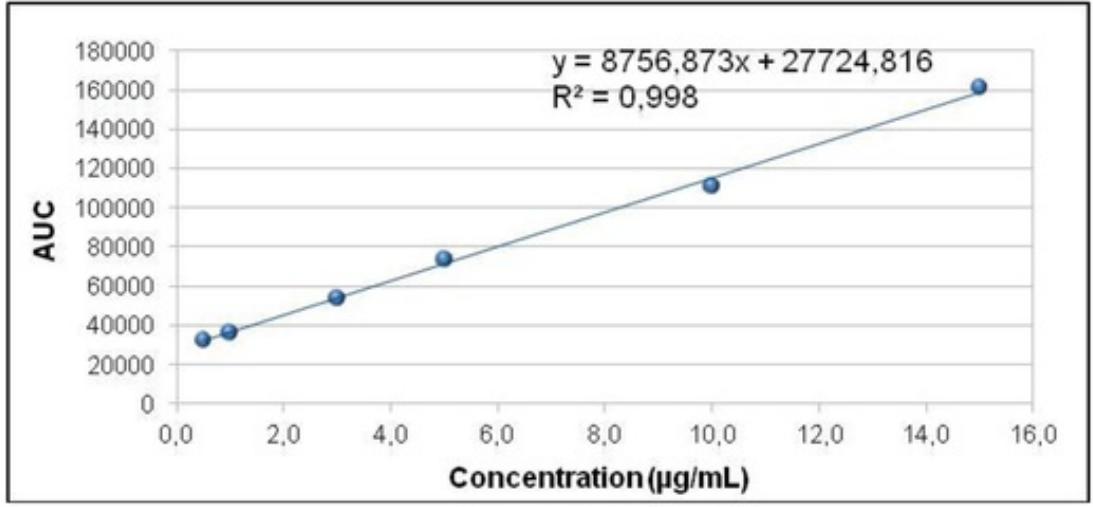

FIGURE 1. Linearity of INH concentration and AUC

Table 2 shows the results of accuray and precision. The accuracy of of this method are shown by $\%$ recovery of intraday and interday sampel for $0.5 ; 5.0$, and $15.0 \mu \mathrm{g} / \mathrm{mL}$ concentration, which are $100.79 \%, 108.91 \%$, and $92.19 \%$, respectively and $101.73 \%, 99.63 \%$, and $82.75 \%$, respectively. The intraday precision is defined as CV (\%) from the concentration of $0.5 ; 5.0$ and $15.0 \mu \mathrm{g} / \mathrm{mL}$ are $5.24 \%, 0.79 \%$ and $2.83 \%$, respectively. Furthermore, 
the interday precision on those particular concentration are $4.86 \%, 2.18 \%$, and $2.01 \%$ respectively.

\begin{tabular}{|c|c|c|c|c|}
\hline $\begin{array}{l}C^{\text {Concentration }} \\
23^{(\mu \mathrm{g} / \mathrm{mL})}\end{array}$ & $\begin{array}{c}\text { Mean } \pm \text { SD } \\
(\mu \mathrm{g} / \mathrm{mL})\end{array}$ & $\begin{array}{l}\text { Precision } \\
\text { (CV \%) }\end{array}$ & $\begin{array}{c}\text { Accuracy } \\
\text { (R\%) }\end{array}$ & Required criteria \\
\hline \multicolumn{5}{|l|}{ Intraday $(\mathrm{n}=5)$} \\
\hline $\begin{array}{c}0,5 \\
5\end{array}$ & $\begin{array}{l}0,50 \pm 0,03 \\
5,45 \pm 0,04\end{array}$ & $\begin{array}{l}5,24 \% \\
0,79 \%\end{array}$ & $\begin{array}{l}100,79 \% \\
108,91 \%\end{array}$ & \\
\hline $\begin{array}{c}15 \\
\text { Interday }(\mathrm{n}=5)\end{array}$ & $13,83 \pm 0,39$ & $2,83 \%$ & $92,19 \%$ & $\begin{array}{c}\text { Precision }=\mathrm{CV} \leq 15 \% \\
\text { Accuracy }=80-120 \%\end{array}$ \\
\hline $\begin{array}{c}0,5 \\
5 \\
15\end{array}$ & $\begin{array}{c}0,51 . \pm 0,02 \\
4,98 \pm 0,11 \\
12,41 \pm 0,25\end{array}$ & $\begin{array}{l}4,86 \% \\
2,18 \% \\
2,01 \%\end{array}$ & $\begin{array}{c}101,73 \% \\
99,63 \% \\
82,75 \%\end{array}$ & \\
\hline
\end{tabular}

\section{DISCUSSION}

Our study found that the method used in HPLC is valid and reliable. HPLC has high selectivity and sensitivity, also it can measure the component of sample until nanogram limit using uv deector. Plasma has many components which may affect the isoniazide concentration measurement. Thus, using HPLC is appropriate method to measure isoniazide concentration [13]. The validation which defined in this study were system suitability, linearity, LoD and LoQ, accuracy and precision [8].

The suitability system was performed before the validation procedures to assure that HPLC can work appropriately during the analysis $[14,16]$. This suitability system test assures that the chromatography has good reproducibility and resolution for the analysis [17]. Linearity was performed to understand the association between the real concentration of isoniazide and the instrument response $[16,18]$.

Accuracy was defined to assure that the method used in the analysis can show the concentration of sample is almost similar to the real concentration [14]. The precision was performed to assure that the repeated measurement has similar results of concentration $[16,18]$.

Previous study about rifampicin validation method for TDM using stirbar-sorptive extraction/HPLC-UV showed that the method could be applied in real situation due to the similar effectivity to liquid-liquid extraction/HPLC-UV. The intraassay and interassay precision and accuracy were performed in the concentration less than 25.0 microgram $/ \mathrm{mL}$ and had the results of less than $10 \%$. Other parameters also met the criteria for validation [19]. However, previous other study used Hydrophylic Interaction Liquid Chromathoghraphy (HILIC). The benefit of using HILIC was the ion-pair reagent of mob 2 phase was free detected. This method could be applied in the TDM method, due to the precision and accuracy were less than $10 \%$ and the limit of quantification was $4 \mathrm{ng} / \mathrm{ml}$ for isoniazid and rifampicin [21]. In the HPLC method, the modification of mobile phase component is required due to the character of the drugs. In this study, isoniazid has hydrophilic character thus we only used acetonitrile and aquabidest as the mobile phase. 13

The other method for TDM of antituberculosis is matrix-assisted laser desorption/ionization source equipped with tandem time-of-flight (MALDI-TOF/TOF) mass spectrometry. This method was introduced by Sirgel et al and presented that the minimal concentration detected using this method was until $0.08 \mathrm{pmol} / \mathrm{microL}$ ) [20]. The qualitative method of rifampicin and isoniazid ingestion also performed in previous study using non-invasive method. This procedure presented that the qualitative method was as effective as the method used in HPLC [21]

Many methods have been performed in the previous studies with valid results of antituberculosis TDM method. However, we need to consider the instrument which is available in our country such as HPLC-UV. Regarding to the budget in performing the TDM method, it is not possible to do the TDM in all tuberculosis patients. We need to make the priority for patients selection such as; ineffective treatment and patients with multidrug resistance of antituberculosis. 


\section{CONCLUSION}

According to the results it can be concluded that the use of HPLC has met the criteria of accuracy, precision, suitability of the system, linearity, LoD and LoQ. Such methods have validity in accordance with the required Anonymous (2001) and Anonymous (2005) so that the validation method can be used to establish the levels of INH in the plasma in the handling of patients with tuberculosis as well as an effort to monitor the effectiveness of treatment in the activities of Therapeutic Drug Monitoring (TDM).

\section{REFERENCE}

9

[1] World Health Organization Report, 2014, Global Tuberculosis Report, available online at 8 p://apps. who.int/iris/bitstream/10665/137094/1/9789241564809_eng.pdf (2014)

[2] G Pinet, Good Practice in Legislation and Regulations For TB Control: An Indicator of Political Will (World 6 alth Organization, Geneva, 2001)

[3] A. Babalik, H. Arda, N. Bakirci, S. Ağca, K. Oruç, S. Kiziltaş, G. Cetintaş, H.C. Calişir, Tubertoraks, 60, $136-$ 144 (2012)

[4] 16 amappa, G.P. Aithal, J. Clin. Exp. Hepatol, 3, 37-49 (2013).

[5] V.J. Navarro, J.R. Senior, N. Engl. J. Med., 354, 731-739 (2006).

[6] J.J. Saukkonen, D.L.22 n, R.M. Jasmer, S. Schenker, J.A. Jereb, C.M. Nolan, C.A. Peloquin, F.M. Gordin, D Nunes, D.B. Strader, Am. J. Respir. Crit. Care Med., 174, 935-952 (2006).

[7] J.J. Saukkonen, K. Powell, J.A. Jereb, Am. J. Respir. Crit. Care Med., 15, 598-9 (2012).

[8] C A Peloquin, Drugs, 62, 2169-83 (2002)

[9] A. 20 ultan, C.A. Peloquin, Drugs, 74, 839-54 (2014)

[10] S.C. Sweetman, Martindale 36 The Complete Drug Reference, (The Pharmaceutical Press, London, 1999).

[11] S. Kayhan, and A. Akgunes, African Journal of Pharmacy and Pharmacology, 5, 2035-41 (2011

[12]A. Rahman, Hubungan Kadar Hidrazin (Metabolit Isoniazid) Dengan Kadar Sgpt Pada Akhir Fase Intensif Pengobatan Pasien Tuberkulosis Paru. Tesis, Universitas Gadjah Mada, Yogyakarta, (2013)

[13] I.G. Gandjar dan A. Rohman, Ki 7 a Farmasi Analisis, (Pustaka Pelajar, Yogyakarta, 2007).

[14] Anonymous, US, Departement of Health and Human Services FDA, Guidance for Industry Bioanalytical Method Valid11 h, available at http://www fda.gov/downloads/Drugs/Guidance/ucm070107.pdf (2001).

[15] Anonymous, International Conference on Harmonization (ICH) of Technical Requirements for Registration of 12 maceuticals for Human, Validation of analytical procedures: Text and methodology Q2(R1), available at http://www.ich.org/fileadmin/Public_Web_Site/ICH_Products/Guidelines/Quality/Q2_R1/Step4/Q2_R1_Guid eline.pdf (2005)

[16] Harmita, Buku Ajar Analisis Fisikokimia, (Departemen Farmasi FMIPA UI, Depok, 2006)

[17] A. Kohn, Am Biotechnol Lab., 12 , 44 (1994)

[18]Badan Pengawas Obat dan Makanan, Acuan Stnadar Metode Pengujian,Badan Pengawas Obat dan Makanan, 3 arta, (2013)

[19] MS Balbão, C. Bertucci, M.M. Bergamaschi, R.H. Queiroz, W.R. Malfará, S.A. Dreossi, L. de Paula Mello, 15 Queiroz, J. Pharm. Biomed. Anal., 51, 1078-83 (2010).

[20] 17 Sirgel, J.S. Maritz, A. Venter, G. Langdon, P. J. Smith, P. R. Donald, Int. J. Pharm., 13, 182-7 (2006).

[21]Z. Zhou, X. Wu, Q. Wei, Y. Liu, P. Liu, A. Ma, F. Zou, Anal. Bioanal. Chem., 405, 6323-6335 (2013).

020030-5 


\section{Validation of isoniazid for therapeutic drug monitoring in human plasma by high- performance liquid chromatography}

ORIGINALITY REPORT

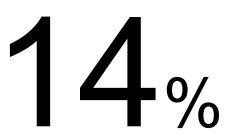

SIMILARITY INDEX

PRIMARY SOURCES

1 www.ijppsjournal.com Internet

35 words $-1 \%$

2 Xu, . "Caffeine", Analytical Methods for Therapeutic Drug Monitoring and Toxicology Xu/Therapeutic Drug 30 words $-1 \%$ Monitoring, 2010.

Crossref

3 Kole, P.L.. "Determination of diclofenac from paediatric urine samples by stir bar sorptive extraction

29 words $-1 \%$ (SBSE)-HPLC-UV technique", Talanta, 20110930 Crossref

4 eprints.ugd.edu.mk Internet

28 words $-1 \%$

5 Cole, David A., Sachin Attavar, and Lei Zhang. "Surface Analysis Methods for Contaminant

25 words $-1 \%$ Identification", Developments in Surface Contamination and Cleaning, 2016.

Crossref

6 Khameneh, Bahman, Bibi Sedigheh Fazly Bazzaz,

Alireza Amani, Javad Rostami, and Nasser Vahdati-

Mashhadian. "Combination of anti-tuberculosis drugs

21 words $-1 \%$ with vitamin $\mathrm{C}$ or NAC against different

Staphylococcus aureus and Mycobacterium tuberculosis strains",

Microbial Pathogenesis, 2016.

Crossref

7 www.islandscholar.ca 
8 M UPLEKAR. "The WHO Stop TB Strategy for the coming decade", Tuberculosis, 2009

20 words $-1 \%$ Crossref

9 Tebruegge, Marc, Nicole Ritz, Nigel Curtis, and Delane Shingadia. "Diagnostic tests for childhood 20 words $-1 \%$ tuberculosis - past imperfect, present tense and future perfect?

:", The Pediatric Infectious Disease Journal, 2015.

Crossref

10 www.nims.go.jp

Internet

20 words $-1 \%$

11 apb.tbzmed.ac.ir

Internet

19 words $-1 \%$

12 ccj.springeropen.com

Internet

18 words $-1 \%$

13 onlinelibrary.wiley.com

Internet

17 words $-1 \%$

14 Takashi Nakai. "Carbon Nanotube Stationary Phase in

17 words $-1 \%$

a Microfabricated Column for High-Performance Gas

Chromatography", AIP Conference Proceedings, 2009

Crossref

15 www.chemweb.com

Internet

16 words $-1 \%$

16 Carol R. Gardner. "Sinusoidal Cells in Liver Injury and Repair", Hepatotoxicity, 12/12/2007

15 words $-<1 \%$ Crossref

17 Shipkova, Maria, and Dobrin Svinarov. "LC-MS/MS as a tool for TDM services: Where are we?",

14 words $-<1 \%$ Clinical Biochemistry, 2016.

Crossref

18 Akira Kotani. "Baseline Noise in High-Performance Liquid Chromatography with Electrochemical

14 words $-<1 \%$ 
19 scitation.aip.org

Internet

13 words $-<1 \%$

20 Belal, Fathalla F., Mohie K. Sharaf El-Din, Manal I.

Eid, and Rania M. El-Gamal. "Micellar HPLC

11 words $-<1 \%$ method using monolithic column for the simultaneous determination of linezolid and rifampicin in pharmaceuticals and biological fluids", Analytical Methods, 2013. Crossref

21 repositorio.ufla.br Internet

10 words $-<1 \%$

22 www.labome.org

Internet

9 words $-<1 \%$

23 Bei Yang. "Determination of apomorphine in canine plasma by liquid chromatography-electrospray

9 words $-<1 \%$ ionization mass spectrometry and its application to a pharmacokinetic study", Journal of Separation Science, 09/2006 Crossref

24 Wang, Q., X. Song, F. Zhang, and Y. Liu. "Determination of 5-Fluorouracil in Serum 9 words $-<1 \%$ Microsamples by a High-Performance Liquid Chromatographic Method and its Application to Pharmacokinetic Studies in Rats", Journal of Chromatographic Science, 2008. Crossref 